\title{
Descriptors of Posidonia oceanica meadows: Use and application
}

C. Pergent-Martini ${ }^{\mathrm{a}}$, V. Leoni ${ }^{\mathrm{a}}$, V. Pasqualini ${ }^{\mathrm{a}}$, G.D. Ardizzone ${ }^{\mathrm{b}}$, E. Balestri ${ }^{\mathrm{c}}$, R. Bedini ${ }^{\mathrm{d}}$, A. Belluscio ${ }^{\mathrm{b}}, \mathrm{T}$. Belsher $^{\mathrm{e}}$, J. Borg ${ }^{\mathrm{f}}$, C.F. Boudouresque ${ }^{\mathrm{g}}$, S. Boumaza ${ }^{\mathrm{h}}$, J.M. Bouquegneau ${ }^{\mathrm{i}}$, M.C. Buia ${ }^{\mathrm{j}}$, S. Calvo ${ }^{\mathrm{k}}$, J. Cebrian ${ }^{\mathrm{l}}$, E. Charbonnel $^{\mathrm{g}}$, F. Cinelli ${ }^{\mathrm{c}}$, A. Cossu ${ }^{\mathrm{m}}$, G. Di Maida ${ }^{\mathrm{k}}$, B. Dural ${ }^{\mathrm{n}}$, P. Francour ${ }^{\mathrm{o}}$, S. Gobert ${ }^{\mathrm{i}}$, G. Lepoint ${ }^{\mathrm{i}}$, A. Meinesz ${ }^{\mathrm{o}}$, H. Molenaar ${ }^{\mathrm{o}}$, H.M. Mansour ${ }^{\mathrm{p}}$, P. Panayotidis ${ }^{\mathrm{q}}$, A. Peirano ${ }^{\mathrm{r}}$, G. Pergent ${ }^{\mathrm{a}}$, L. Piazzic ${ }^{\mathrm{c}}$, M. Pirrotta ${ }^{\mathrm{k}}$, G. Relini ${ }^{\mathrm{s}}$, J. Romero $^{\mathrm{t}}$, J.L. Sanchez-Lizaso " ${ }^{\mathrm{u}}$, R. Semroud ${ }^{\mathrm{h}}$, P. Shembri ${ }^{\mathrm{f}}$, A. Shili ${ }^{\mathrm{v}}$, A. Tomasello ${ }^{\mathrm{k}}$, B. Velimirov ${ }^{\mathrm{w}}$

${ }^{a}$ Equipe Ecosystèmes Littoraux, Faculty of Sciences, University of Corsica, BP 52, 20250 Corte, France

${ }^{b}$ Department of Animal and Human Biology, University of Rome "La sapienza", 32, 00185, Rome, Italy

${ }^{c}$ Dipartimento di Scienze delГUomo e delГAmbiente, Università di Pisa, Via A. Volta 6, 56126 Pisa, Italy

${ }^{d}$ Istituto di Biologia ed Ecologia Marina di Piombino, piazza Bovio 3-4, 57025 Piombino, Italy

${ }^{\mathrm{e}}$ Ifremer, Station de Sète, Av. Jean Monnet, BP 171, 34203 Sete Cedex, France

${ }^{f}$ Department of Biology, Faculty of Sciences, University of Malta, Msida, Malta

${ }^{g}$ GIS Posidonie-Université de la Méditerranée, Luminy, Case 901, 13288 Marseille cedex9, France

${ }^{h}$ Institut des Sciences de la Mer et de l'Amenagement du Littoral, B.P. 54, Sidi Fredj 42321, Alger, Algeria

${ }^{i}$ Laboratoire d' Océanologie, Université de Liège, Sart-Tilman, B6, 4000 Liège, Belgique

'Stazione Zoologica 'Anton Dohrn' di Napoli; Benthic Ecology Laboratory, P.ta S. Pietro, 1-80077 Ischia, Italy

${ }^{\mathrm{k}}$ Dipartimento di ingegneria idraulica ed applicazioni ambientali, University of Palerme, 90128 Palermo, Italy

'Marine Environmental Sciences Consortium, Dauphin Island Sea Lab., PO Box 369-370, AL 36528 USA

${ }^{\mathrm{m}}$ Dipartimento di botanica ed Ecologia vegetale, Università di Sassari, Via Muroni 25, 07100 Sassari, Italy

${ }^{n}$ Ege University, Faculty of Science, Department Biology, Izmir, Turkey

- Laboratoire d'Environnement Marin Littoral, Université de Nice, 06108 Nice, Cedex 02, France

${ }^{\mathrm{p}}$ Faculty of science, Université d'Alexandrie, Alexandrie, Egypte

${ }^{q}$ National Center of Marine research, 16604 Athens, Greece

${ }^{\mathrm{r}}$ ENEA-Marine Environment Research Center, PO Box 224, 19100 La Spezia, Italy

${ }^{\mathrm{s}}$ Istituto di Zoologia, Università di Genova, Via Balbi 5, 16126 Genova, Italy

${ }^{t}$ Departamenot d'Ecologia, Universitad de Barcelona, diagonal 645, 08028 Barcelona, Spain

"Departamento de Ciencias Ambientales, Universidad de Alicante, Ap. 99, 03080, Alicante, Spain

${ }^{v}$ Universié de Tunis, 103 Av 20 Mars, Le Bardo, 2000 Tunis, Tunisie

${ }^{\mathrm{w}}$ Institute of Medical Biology, University of Vienna, 1090 Vienna, Austria

\begin{abstract}
The conservation of the coastal marine environment requires the possession of information that enables the global quality of the environment to be evaluated reliably and relatively quickly. The use of biological indicators is often an appropriate method. Seagrasses in general, and Posidonia oceanica meadows in particular, are considered to be appropriate for biomonitoring because of their wide distribution, reasonable size, sedentary habit, easy collection and abundance and sensitivity to modifications of littoral zone. Reasoned management, on the scale of the whole Mediterranean basin, requires standardized methods of study, to be applied by both researchers and administrators, enabling comparable results to be obtained. This paper synthesises the existing methods applied to monitor $P$. oceanica meadows, identifies the most suitable techniques and suggests future research directions. From the results of a questionnaire, distributed to all the identified laboratories working on this topic, a list of the most commonly used descriptors was drawn up, together with the related research techniques (e.g. standardization, interest and limits, valuation of the results). It seems that the techniques used to study meadows are rather similar, but rarely identical, even though the various teams often refer to previously published works. This paper shows the interest of a practical guide that describes, in a standardized way, the most useful techniques enabling $P$. oceanica meadows to be used as an environmental descriptor. Indeed, it constitutes the first stage in the process.
\end{abstract}

Keywords: Posidonia oceanica ; mediterranean sea ; bioindicator ; standardized methods ; advantages ; limits

\section{Introduction}

Human activities can disturb the stability and the conservation of coastal marine environment. The use of biological indicators seems to be the most suitable investigation method for research into applied ecology, because it enables the quality of an environment to be characterized in an integrated way. Indeed, the presence of an organism in a specific environment tends to prove that its ecological needs are globally satisfied, whereas its disappearance testifies to a change in the environment; that is the principle of "sentinel species" (Blandin, 1986).

Concerning the marine environment, the first indicators to be used, filter feeders, are still the most commonly used for biomonitoring, in many countries (e.g. Mussel Watch; Thomann et al., 1995; Adami et al., 2002; CIESM, 2002; Lionetto et al., 2003). For some years, species of aquatic vegetation have also been closely studied, according to their ability to accumulate pollutants and specially trace-metals (Nienhuis, 1986; 
Guilizzoni, 1991; Castilla, 1996; Pergent-Martini and Pergent, 2000; Storelli et al., 2001). Seagrasses are increasingly used as a biological indicator of the quality of the environment (Fourqurean and Cai, 2001, Bhattacharya et al., 2003); because of their ecological roles (Costanza et al., 1997) added to their wide distribution, sedentary habit, and sensitivity to modifications of littoral zone (Short and Wyllie-Echeverria, 1996; Pergent-Martini and Pergent, 2000; Linton and Warner, 2003; Yamamuro et al., 2003). In the Mediterranean sea, a great deal of research has been dedicated to Posidonia oceanica (L.) Delile, an endemic marine magnoliophyta that constitutes a key species (Bianchi et al.,1989). P. oceanica meadows play a major ecological, sedimentary and economic role (Bell and Harmelin-Vivien, 1983; Jeudy de Grissac and Boudouresque, 1985; Gambi et al., 1989; Romero et al., 1992; Duarte, 1999; Duarte, 2002). Moreover, Posidonia oceanica seems to be a reliable bioindicator (Augier, 1985; Pergent, 1991; Pergent-Martini and Pergent, 2000), according to: (i) their sensitivity to disturbances, as demonstrated by a number of reports of meadow regression due to various causes (Delgado et al., 1999; Ruiz et al., 2001; Ruiz and Romero, 2003); (ii) its wide distribution along the Mediterranean coast (Pasqualini et al., 1998; Procaccini et al., 2003) and (iii) the good knowledge about specific response of the plant and of its associated ecosystem to specific impact (Romero et al., 2005). Furthermore, this species is able to inform about present and past level of trace-metals in the environment (Pergent-Martini, 1998).

The aim of this study is to identify the descriptors and the most commonly used methods of investigation, then to make a synthesis including the measurement techniques in order better to define the limits of use and the respective advantages of each one.

This approach constitutes the first step to allow the use of $P$. oceanica, at the scale of the Mediterranean basin, to assess good ecological status of coastal zones.

\section{Materials and methods}

To investigate the descriptors used to assess the good ecological status of Posidonia ecosystem, systematic data collection are chosen, using the same set of questions to each people (Weller and Romney, 1988). A detailed questionnaire was produced and sent to 84 people, representing 41 laboratories. These laboratories were listed according to their actual or previous studies on $P$. oceanica meadows. The questionnaire covers all the levels of organization of the $P$. oceanica ecosystem because modifications of environmental conditions can impact the population or the plant itself. Descriptors take into account the structure of the meadow (e.g. bathymetric extension, spatial distribution), the ecosystem (associated fauna and flora) and the status of the plant (e.g. leaf shoot structure, production).

To facilitate the answers, the descriptors commonly referenced in the literature were listed, with a distinction between field or laboratory measurements (Table 1). For each descriptor, several questions were proposed (see an example on Fig. 1; Strauss and Corbin, 1998). "Practical and structural" questions allow initially to identify how the method corresponding to one descriptor is implemented, its advantages or disadvantages, then "sensitizing" questions concern information supplied by the use of one descriptor, its interest and significance (Strauss and Corbin, 1998). In addition, "guiding" questions are helpful to highlight specific and complementary point (Strauss and Corbin, 1998). The answers of the questionnaire can be done using dichotomous (yes/no) or multiple choices, but so with free answers, laboratories could propose additional remarks and/or descriptors (Fig. 1 ; Weller and Romney, 1988). Results were analysed using simple matrix (Strauss and Corbin, 1998). 
Table 1 List of the descriptors, and the specific parameters associated, considered in the questionnaire

Measures in situ

Upper depth limit of the meadow

Position

State

Position

State

Lower depth limit of the meadow

Observations

Density (number of shoots per surface unit)

Bottom cover (surface occupied by the meadow, \%)

Structure of the matte

Measure in the laboratory

Leaf biometry

Datation measurements

Biochemical and chemical composition

Contamination

Species associated to the meadows
Observations

Measures

Measures

Measures and observations
Presence of ripple-marks

Granulometry of the sediment

Presence of died mattes

Presence of litter

Presence of algae

Resistance to erosion

Compactness

Homogeneity

Physicochemical composition

Measures and observations Presence of channels intermatte

Presence of "cliff of dead matte"

Percentage of plagiotropic rhizomes

Erosion of rhizomes

Burial of rhizomes

Evaluation of biodiversity

Measures and observations Shoot composition

Origin of broken leave

Lepidochronology

Plastochrone interval

Speed of rhizomes growth

Number of leaves per year

Primary production Dating of

paleoflowering

Proteins

Lipids

Carbohydrate

Carbon

Hydrogen

Nitrogen

Phosphorus

Enzymes of stress

PHA

PBC

Heavy metals

Borer organisms

Associated fauna

Epiphytic coverage

Bacterial populating 
Fig. 1. General information required for each descriptors: example for the lower depth limit of the Posidonia oceanica meadow.

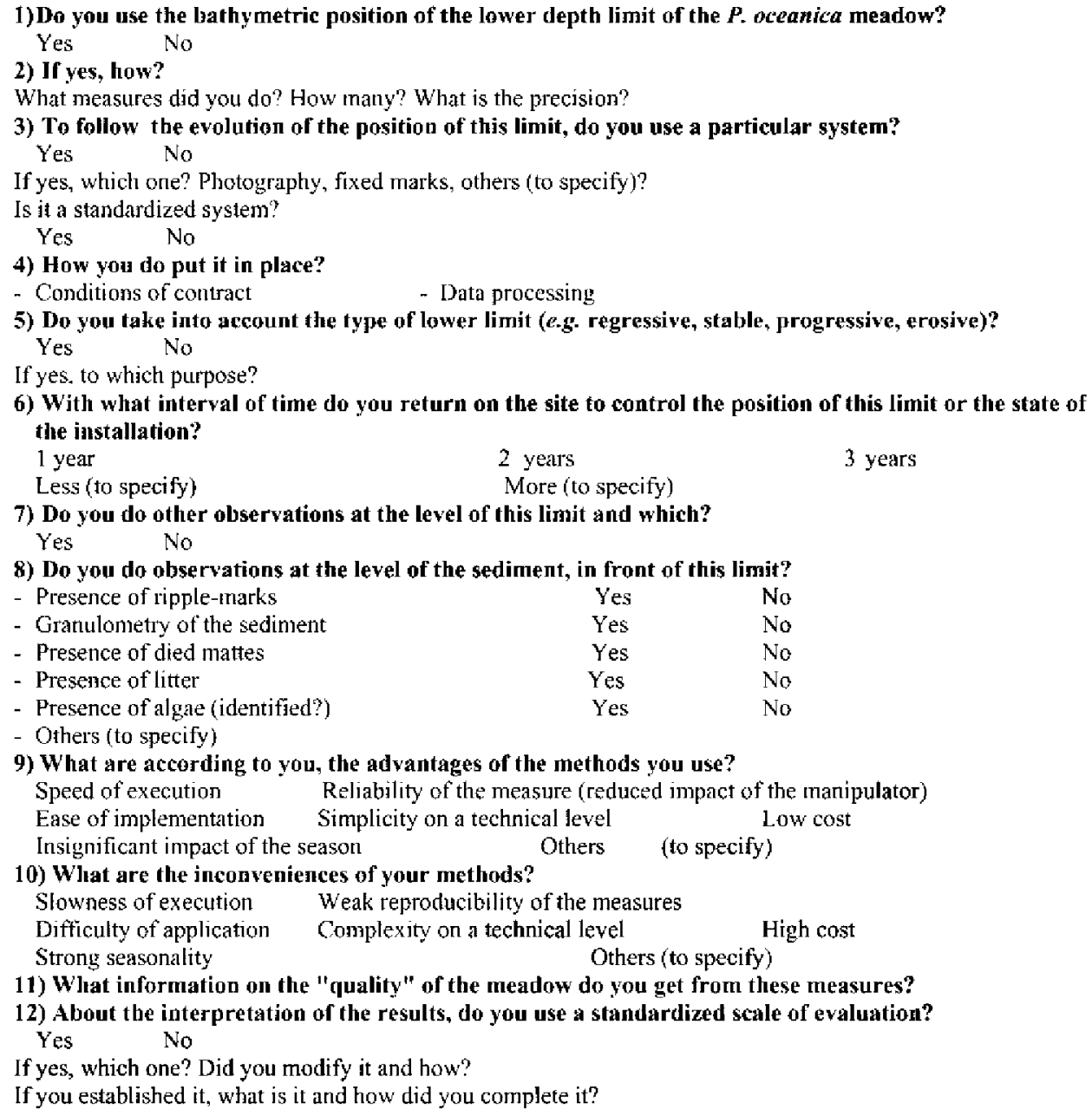

\section{Results}

More than $60 \%$ of the laboratories contacted returned the questionnaire. Below, we present an analysis of the responses for each descriptor (Fig. 2); the percentages are expressed in function of the laboratories, which answered the question. All the descriptors of the meadows identified in the questionnaire received at least six responses.

\subsection{Lower depth limit}

\subsubsection{Measurements}

Eighty-eight percent of the laboratories take into account the bathymetric position of the lower depth limit (depthmeter, bathymetric sounder; Fig. 2) and/or the geographical position (GPS, points taken from the sea to the coast). The precision of the geographical localization of the limit varies according to the method used (from 1 to about $10 \mathrm{~m}$ ). It is noticeable that $73 \%$ of the laboratories take into account the type of lower depth limit found, as defined by Meinesz and Laurent (1978) and Boudouresque and Meinesz (1982). Fifty-five percent of the laboratories complement their observations by taking measurements of the meadow, and $86 \%$ by measurements of the sediment ahead of this limit. These observations mainly concern the density of the meadows (75\%), and the presence of dead matte $(100 \%)$, ripple-marks $(95 \%)$ and litter $(84 \%)$. Seventy-seven percent of the laboratories monitor the position of this limit over time, the methods most commonly used being the setting up of fixed marks, the taking of in situ photographs and/or the use of a side scan sonar (Fig. 3). More rarely, laboratories (5\%) use a remote operated vehicle (ROV; Ardizzone and Belluscio, 1992). These measures are generally standardized ( $71 \%$ for the fixed marks, $55 \%$ for the photographs in situ), and sometimes laboratories specify that they refer to the protocol set up by the Posidonia Monitoring Network, as defined by Boudouresque et al. (2000). The interval between return visits to the site ranges from about 6 months to 5 years, but in most cases it is annual (47\%). 
Fig. 2. Rate of study of various descriptors of Posidonia oceanica (\% and number of expressed answers given according to the total number of laboratories having answered).

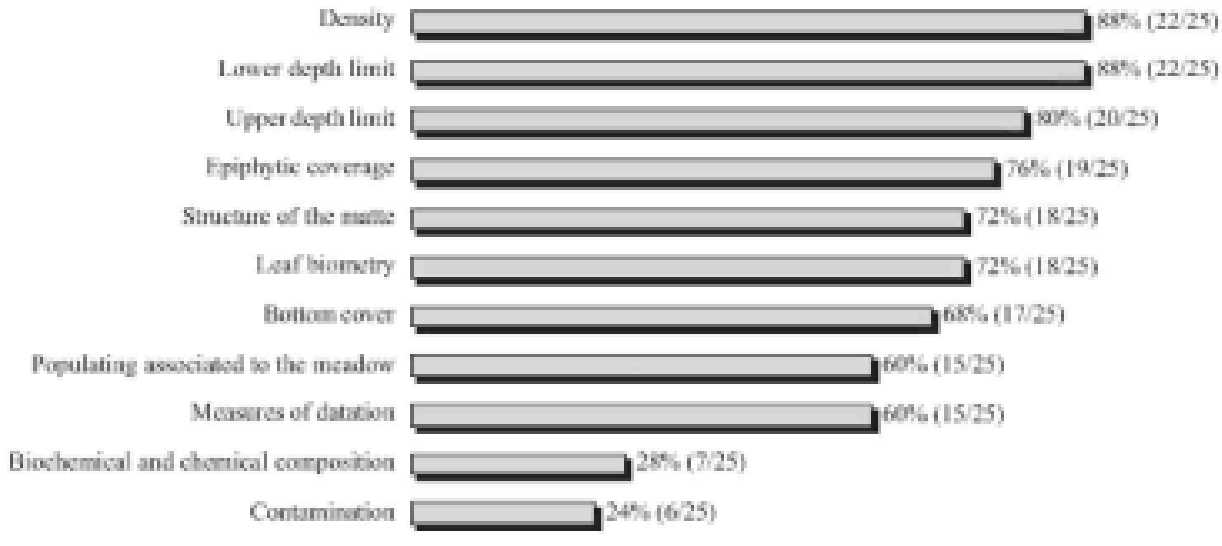

\subsubsection{Interpretation}

Thirty-two percent of the laboratories use a standardised scale of evaluation to analyse their results (density, typology). The scales used are those defined by Pergent et al. (1995) (57\%) and Meinesz and Laurent (1978) $(29 \%)$.

\subsubsection{Advantages and limits}

Whatever the method used, it gives reliable results. The method based on fixed marks is attractive because it is technically simple and easy to implement. The use of side scan sonar seems to be limited according to its technical complexity and the high cost of application, even if it is able to cover large surface areas in a quite short time (Fig. 3).

\subsubsection{Synthesis}

Eighty-two percent of the laboratories consider that the lower limit provides pertinent information about the quality of the meadow and the environment in general, especially about water transparency and hydrodynamics. The type of limit found can provide information about the dynamics of the meadow (regression, progression) in relation to the evolution of environmental conditions (stability, improvement, damage).

\subsection{Upper depth limit}

\subsubsection{Measurements}

The bathymetric position of the upper limit is also a much used descriptor (Fig. 2); laboratories take into account its depth and its geographic position. Seventy percent of the laboratories add to this information, observations of the density $(57 \%)$, the bottom cover $(21 \%)$, the presence of other species $(21 \%)$ or the characteristics of the substrate (7\%). The precision concerning the geographic localization of this limit fluctuates, according to the method used, but seems similar to that observed for the lower limit. Seventy-five percent of the laboratories monitor this limit. The interval between two observations varies considerably (from 6 months to 10 years), but is, more often, annual $(60 \%)$. The methods most commonly used are the setting up of fixed marks and the use of aerial diachronic photographs. There are generally standardized methods $(67 \%$ for the fixed marks and $27 \%$ for the aerial photographs) in direct relation with the protocol implemented in the Posidonia Monitoring Network, defined by Boudouresque et al. (2000).

\subsubsection{Interpretation}

No laboratories mentioned the use of a standardized evaluation scale.

\subsubsection{Advantages and limits}

Both fixed marks and aerial photographs enable reliable results to be obtained and are easy to set up in situ (Fig. 4). The use of fixed marks requires a monitoring of these structures but are less expensive, while the use of aerial photographs is less constraining, but more expensive.

\subsubsection{Synthesis}

The upper limit, due to its localization at the edge of the coastline, gives very relevant data concerning natural environmental changes (e.g. hydrodynamics, sedimentary balance) but also changes linked to human action (e.g. 
coastal developments, anchorages).

\subsection{Density}

\subsubsection{Measurements}

The density descriptor is used by $88 \%$ of the laboratories (Fig. 2). 0.2 and $0.4 \mathrm{~m}$ size quadrat are generally used to measure the number of shoots (Table 2). Ninty-one percent of the laboratories always use the same quadrat, whatever the depth or the season. Although some laboratories replace the $0.4 \mathrm{~m}$ quadrat by $0.2 \mathrm{~m}$ quadrat along the lower depth limits. For both types of quadrat, the most common number of replicates is 10 (Table 2). Only $41 \%$ of the laboratories count divided shoots as distinct shoots but $45 \%$ of the laboratories did not express an opinion.

Fig. 3. Advantages and difficulties of the methods used for the monitoring of the position of the lower depth limit position (\% and number of expressed answers according to the number of laboratories using this descriptor).
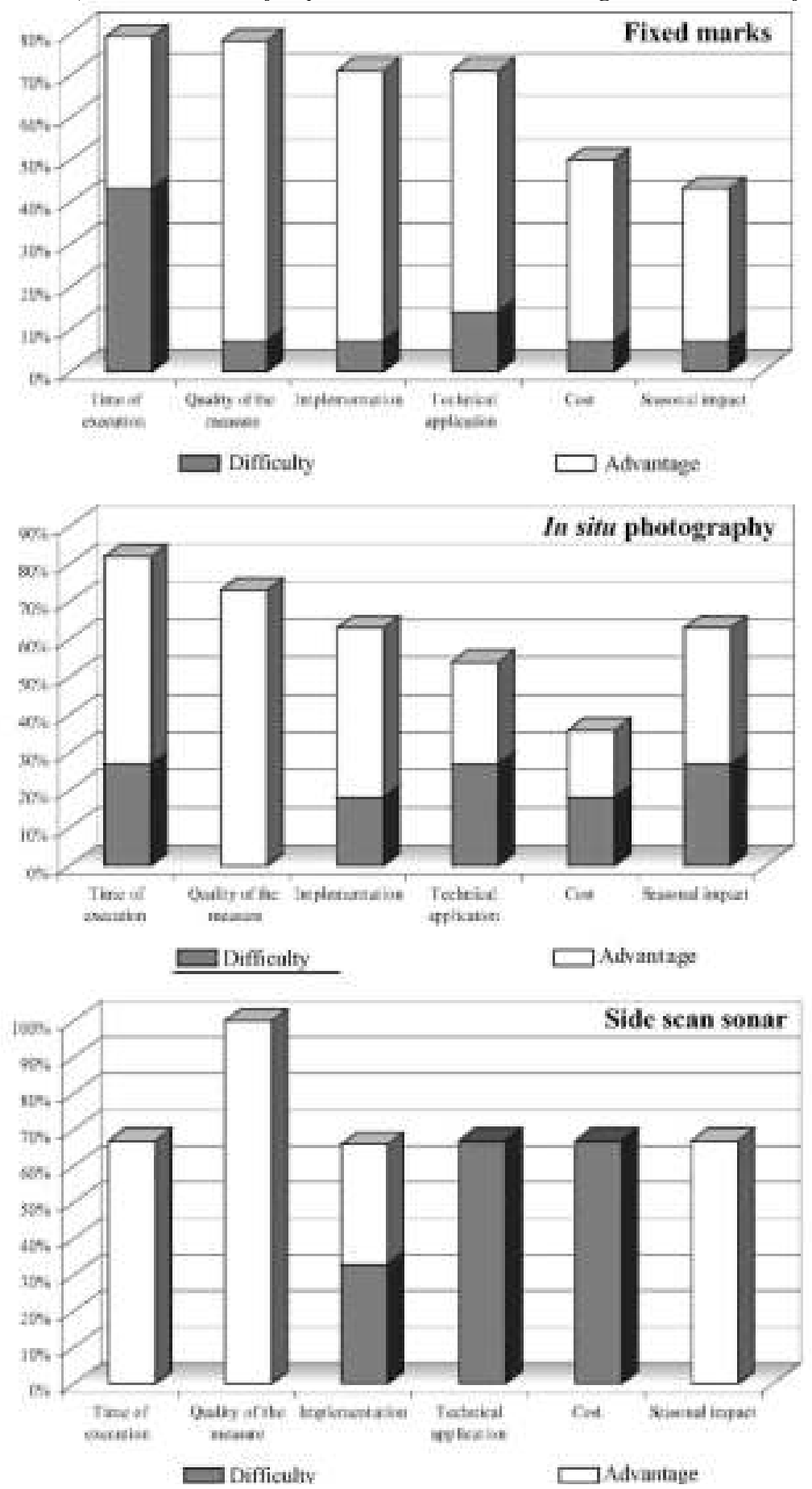
Fig. 4. Advantages and difficulties of the methods used for the monitoring of the position of the upper depth limit (\% and number of expressed answers according to the number of laboratories using this descriptor).

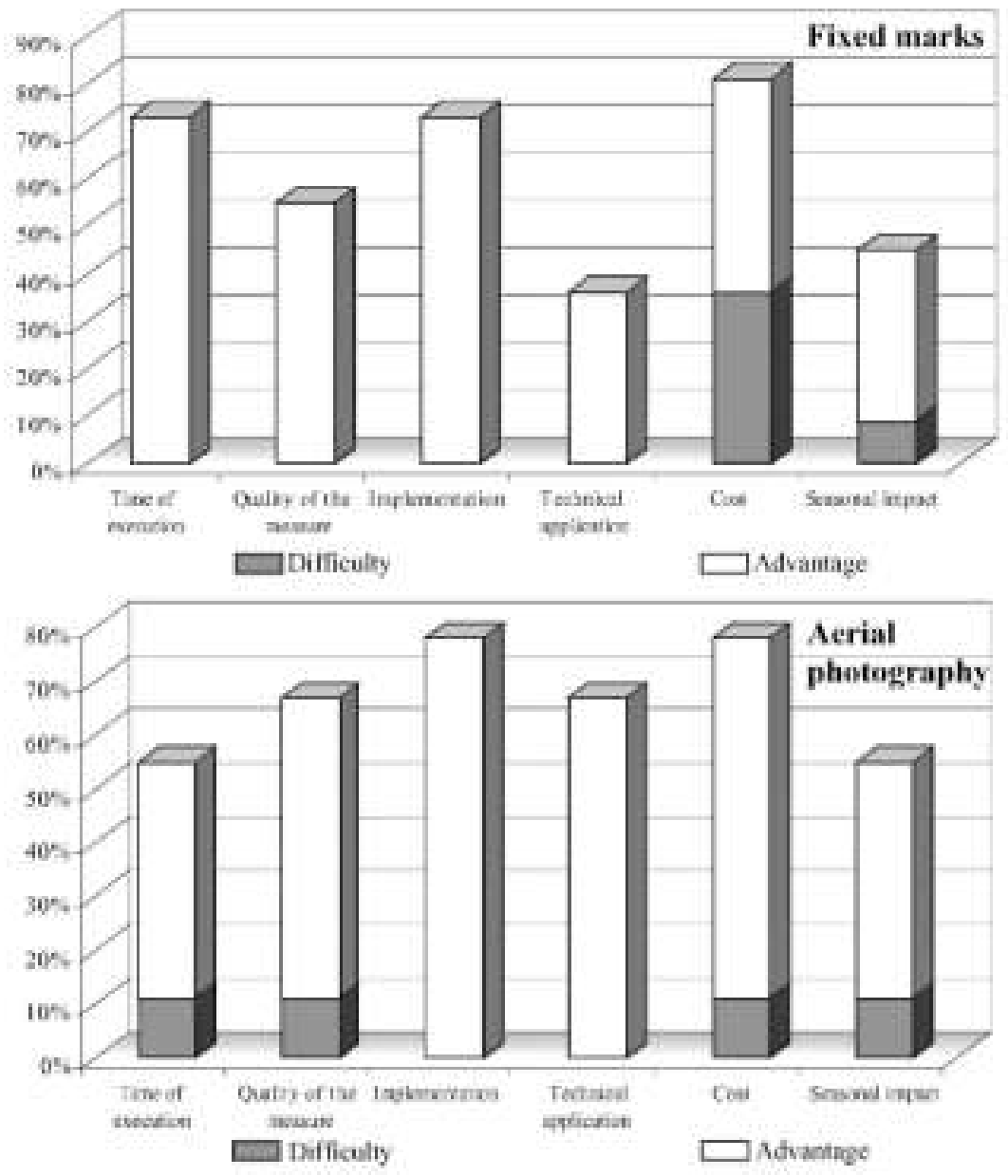

Table 2 Type of quadrat and number of replicates used in order to evaluate the density of the meadows (percentage of answers expressed according to the number of laboratories using the density descriptor then according to the type of quadrat)

\begin{tabular}{llll}
$\begin{array}{l}\text { Shape and size of the surface } \\
\text { of measure }(\mathrm{m})\end{array}$ & Application of the format & Number of replicates $a$ & $\begin{array}{l}\text { Application of the } \\
\text { number of replicates }\end{array}$ \\
\hline Square: $0.2 \times 0.2$ & $23 \%(5 / 22)$ & 5 & $20 \%(1 / 5)$ \\
& & $5-10$ & $20 \%(1 / 5)$ \\
& & 10 & $40 \%(2 / 5)$ \\
& & 18 & $20 \%(1 / 5)$ \\
& $23 \%(5 / 22)$ & $3-5$ & $20 \%(1 / 5)$ \\
Square: $0.4 \times 0.4$ & 10 & $60 \%(3 / 5)$ \\
& & $10-30$ & $20 \%(1 / 5)$ \\
Square: $0.25 \times 0.25$ & $18 \%(4 / 22)$ & 3 & $50 \%(2 / 4)$ \\
& & 20 & $25 \%(1 / 4)$ \\
Square: $0.5 \times 0.5$ & $14 \%(3 / 22)$ & 3 & $33 \%(1 / 3)$ \\
& & 5 & $33 \%(1 / 3)$ \\
Circle: diameter de 0.3 & $5 \%(1 / 22)$ & $30-50$ & $100 \%(1 / 1)$ \\
Square: $0.3 \times 0.3$ & $5 \%(1 / 22)$ & 5 & $100 \%(1 / 1)$ \\
Square: $0.35 \times 0.35$ & $5 \%(1 / 22)$ & $3-5$ & $100 \%(1 / 1)$ \\
Square: $1 \times 1$ & $5 \%(1 / 22)$ & 5 & $100 \%(1 / 1)$ \\
No answer & $23 \%(5 / 22)$ & & \\
\hline
\end{tabular}




\subsubsection{Interpretation}

Concerning the interpretation of the results, $77 \%$ of the laboratories express the results in metre square. Sixty four percent use a standardized scale of evaluation; two scales are used in an equivalent way, the scale of Giraud (1977) and that of Pergent et al. (1995). Other laboratories interpret their results by simple comparison between meadows, situated at the same depth.

\subsubsection{Advantages and limits}

Most of the laboratories consider that this descriptor has numerous advantages: it gives reliable results (59\%), it is easy to implement in situ (59\%), its technical application is simple (73\%) and its cost is low $(59 \%)$. The main drawback is connected to the in situ execution time $(64 \%)$.

\subsubsection{Synthesis}

The majority of laboratories $(86 \%)$ consider that the use of density provides important information, conveying the vitality and dynamics of the $P$. oceanica meadows, and is able to reveal the human impact on the environment.

\subsection{Bottom cover}

\subsubsection{Measurements}

Bottom cover is also a very commonly used descriptor (Fig. 2). Measurement of the bottom cover is generally carried out by direct visual observations, some metres above the bottom, using: (i) a grid designed on a transparent support (Francour et al., 1999); (ii) vertical photography and (iii) evaluation of the shoots repartition into a quadrat. The surface area taken into account and the number of replicas vary according to the author: (i) a square area from 0.16 to $625 \mathrm{~m}$ with 1-60 replicas (59\%); (ii) a circle from 10 to $15 \mathrm{~m}$ (from 78 to $176 \mathrm{~m}^{2}$ ) with two replicas $(6 \%)$ or (iii) a transect of $25 \mathrm{~m}$ long $\left(25 \mathrm{~m}^{2}\right)$ with four replicas $(6 \%$; Table 3$)$.

Table 3 Size, type of surface and number of replicates used to estimate the bottom cover of the meadows (percentage of answers expressed according to the number of laboratories using the bottom cover descriptor)

\begin{tabular}{llll}
\hline Size $\left(\mathrm{m}^{2}\right)$ & Shape & $\begin{array}{l}\text { Number of } \\
\text { replicates }\end{array}$ & Applications \\
\hline 625 & Square & 1 & $6 \%(1 / 17)$ \\
$78-176$ & Circle & 2 & $6 \%(1 / 17)$ \\
40 & Square & 2 & $6 \%(1 / 17)$ \\
25 & Square & 3 & $12 \%(2 / 17)$ \\
10 & Square & $10-50$ & $12 \%(2 / 17)$ \\
$1-5$ & Square & 3 & $6 \%(1 / 17)$ \\
1 & Square & $2-10$ & $12 \%(2 / 17)$ \\
0.16 & Square & $30-60$ & $6 \%(1 / 17)$ \\
25 & Transect & 4 & $6 \%(1 / 17)$ \\
\hline
\end{tabular}

\subsubsection{Interpretation}

Only two laboratories apply a correction factor according to the season and the depth. The results are expressed in percentage of cover but few laboratories $(18 \%)$ use a standardized scale of evaluation; furthermore, no scale seems to predominate (Braun-Blanquet, 1964; Pergent et al., 1995; Francour et al., 1999).

\subsubsection{Advantages and limits}

This method is fast (88\%), easy to implement in situ (59\%), technically simple to apply (88\%) and low cost $(53 \%)$. However, its reliability is not very high, due to the significant influence of the people who carries out the measurements (53\%) and the season (53\%). Furthermore, two laboratories highlighted the problem of turbidity, which can affect the visual estimation.

\subsubsection{Synthesis}

Laboratories consider that bottom cover provides information about the health of the meadows with respect to the quality of the environment (41\%) and the distribution of the meadow over the substrate (macrostructure; $24 \%)$. 


\subsection{Matte structure}

\subsubsection{Measurements}

Seventy-two percent of the laboratories take into account the structure of the matte (Fig. 2). It is assessed through: (i) the presence of channels of intermatte (78\%) and "cliffs" of dead matte" (72\%); (ii) the burial or erosion of the rhizomes (56\%); (iii) the evaluation of the biodiversity of the endofauna (56\%); (iv) the homogeneity, resistance and the compactness of the matte $(44 \%)$; (v) the percentage of plagiotropic rhizomes (39\%); (vi) the thickness of the matte (22\%) and (vii) its physicochemical composition (6\%). These parameters are observed visually (presence, absence, distance or percentage estimation) or by sampling (core samples).

\subsubsection{Interpretation}

Few laboratories $(6 \%)$ use a standardized evaluation scale. However, the scale of Boudouresque et al. (1980) should be mentioned, which is intended to evaluate the erosion of the rhizomes.

\subsubsection{Advantages and limits}

With the exception of the physicochemical composition, the methods used provide relatively reliable results, and are easy to implement and technically easy to use. They are inexpensive and interesting according to their short execution time (50\%). However, some laboratories indicate a significant impact of the season (22\%).

\subsubsection{Synthesis}

The structure of the matte supplies relevant information concerning the health of the meadows (33\%) and more globally the environment, sedimentary dynamics and currents of the studied area $(17 \%)$.

\subsection{Epiphytic coverage}

The descriptor of epiphytic coverage is the most commonly used laboratory measurement (Fig. 2). Sixty-three percent of the laboratories carry out a quantitative analysis (biomass) and 53\% a qualitative analysis (identification of the species). Generally, the use of a standardized evaluation scale for analysing the results is not mentioned by the laboratories, except from that of Morri (1991), which is used in some cases. The advantages of this descriptor are its simplicity of application and its low cost, but it is a time-consuming method, especially for the qualitative study, and seasonal variation complicates its use. The epiphytic coverage provides information on water quality, especially data on nutrients inputs, and specific diversity of this compartment.

\subsection{Leaf biometry}

\subsubsection{Measurements}

Seventy-two percent of the laboratories use the leaf biometry (Fig. 2). With the exception of one laboratory, which estimates it from photographs, this descriptor is applied to shoots collected on field. The number of measured shoots is rather variable: at least 20 shoots (37\%), 10-19 shoots (32\%) or less than 10 shoots (11\%). Usually the laboratories (89\%) distinguish the type of leaves (adult with distinction between limb and petiole; intermediates or juveniles), in particular referring to the protocol of Giraud (1977) (61\%). The main measurements concern: (i) the number of leaves (94\%); (ii) their length (94\%); (iii) their width (89\%) with differences concerning the location of the measurement (usually the central part); (iv) the leaf surface (72\%); (v) the biomass (67\%) and (vi) the presence of dead brown tissue/ necrosis (17\%).

The percentage of broken leaves (without apex) is often noted (78\%) and the origin of this loss (water movement, grazing) is identified by $44 \%$ of the laboratories, which base themselves mainly on the protocol of Boudouresque and Meinesz (1982). Several parameters are calculated with these data, notably the leaf surface area per shoot $(72 \%)$, the "Leaf Area Index" per $\mathrm{m}^{2}(67 \%)$ and the coefficient A (28\%). Other observations are also mentioned: the presence of flowers $(83 \%)$ and/or fruits $(11 \%)$, the aboveground biomass $(33 \%)$ and the belowground biomass $(17 \%)$, the presence of borers $(6 \%)$.

\subsubsection{Interpretation}

Measurements are essentially interpreted by comparison of different areas and sampling periods. A few laboratories (11\%) use a standardized evaluation scale, notably that of Pergent et al. (1995).

\subsubsection{Advantages and limits}

Most of the laboratories consider that these measurements provide reliable results, according to the low impact due to the people carrying out the measurement (53\%). They are easy to implement on laboratory $(58 \%)$, simple to apply on the technical level $(58 \%)$ and low cost $(58 \%)$. The main drawbacks are linked to the execution time $(58 \%)$ and the significant variations due to the season (47\%). 


\subsubsection{Synthesis}

Fifty-six percent of the laboratories consider that the leaf biometry is indicative of the good health status of $P$. oceanica, and therefore of the environmental conditions (e.g. anthropisation of the environment, water movement, action of grazers); in addition, it is an important source of information concerning the dynamics and vegetative growth of the meadows.

\subsection{Datation measurements}

\subsubsection{Measurements}

Sixty percent of the laboratories use this descriptor (Fig. 2). The number of shoots taken into account is variable: at least 20 shoots $(33 \%), 10-19$ shoots $(26 \%)$ or less than 10 shoots $(20 \%)$. More specifically, two methods are used: the lepidochronology (86\%; Pergent, 1990) and the plastochrone interval (33\%; Cebrian et al., 1994). They enable estimation of the number of leaves produced annually $(87 \%)$, the rate of rhizome growth $(80 \%)$, the existence of paleo-flowering (53\%) and the past primary production $(53 \%)$.

\subsubsection{Interpretation}

Measurements can be interpreted by comparison with other stations (e.g. geographic localization, depth, anthropisation) or using a standardized evaluation scale (20\%; Pergent et al., 1995).

\subsubsection{Advantages and limits}

Sixty percent of the laboratories consider that these methods provide reliable measurements and are easy to implement in situ (40\%). Simple to apply from a technical point of view (67\%) and low cost (67\%), they also show negligible seasonal variation (40\%). The main limitation is linked to the execution time $(67 \%)$.

\subsubsection{Synthesis}

Numerous laboratories consider that these datation measurements provide information about: (i) the temporal evolution of above and belowground production; (ii) the rate of sedimentation; (iii) the importance of sexual reproduction; (iv) the dynamics of the meadow and (vi) the reaction to environmental factors.

\subsection{Species associated to the meadow}

\subsubsection{Measurements}

Sixty percent of the laboratories take into account the species associated to the meadow (Fig. 2). These are assessed by the means of the ichthyic population (47\%), the echinoderms population $(40 \%)$ and the cnidaria population (13\%), and/or the presence of other macrophytes $(7 \%)$. These parameters are estimated visually, by identification and assessment directly on field (visual censuses) or after sampling (trawling, nets, suction sampling).

\subsubsection{Interpretation}

Measurements are interpreted by comparison with other stations (e.g. geographic localization, depth, level of anthropisation); no standardized evaluation scale is mentioned.

\subsubsection{Advantages and limits}

Measuring the species associated to a meadow supplies relatively reliable results (53\%), is easy to implement $(53 \%)$, technically easy to apply (40\%), low cost (40\%) and quick to perform (50\%). However, there is a marked seasonal influence, which must be taken into account (47\%).

\subsubsection{Synthesis}

The species associated to the meadow supply relevant information concerning the biodiversity of the study zone $(33 \%)$ and the interactions between the meadow and the species evaluated $(7 \%)$.

\subsection{Chemical and biochemical composition}

\subsubsection{Measurements}

The chemical and biochemical composition of $P$. oceanica are a few used descriptors (Fig. 2). The main elementary analyses concern nitrogen $(71 \%)$, carbon $(71 \%)$, phosphorus $(29 \%)$ and hydrogen $(14 \%)$. Other analyses concern phenolic compounds (29\%) and/or proteins and stress enzymes $(29 \%)$.

\subsubsection{Interpretation}

Measurements are interpreted by comparison with other stations (e.g. geographic localization, depth, level of anthropisation); no standardized evaluation scale is mentioned. 


\subsubsection{Advantages and limits}

While these measurements seem reliable (low impact of the people making the measurements; $57 \%$ ) and easy to implement (57\%), their development is generally limited due to their slowness of execution (71\%), their technical constraints and their high cost (57\%).

\subsubsection{Synthesis}

These descriptors should be developed in the future because they can provide information about the level of plant stress, and seem in adequacy with the level and impact of human activities.

\subsection{Contamination}

\subsubsection{Measurements}

The study of the contamination of $P$. oceanica is also a few used descriptor (Fig. 2). The main measurements concern trace metals, in particular mercury (67\%), copper (50\%), cadmium $(33 \%)$, lead (33\%), zinc (33\%), iron $(17 \%)$, chromium $(17 \%)$ and/ or titanium $(17 \%)$.

\subsubsection{Interpretation}

The results are often interpreted by comparison with other stations (e.g. geographic localization, depth, level of anthropisation); no standardized evaluation scale is mentioned, although a standardized scale could be used (Pergent-Martini et al., 1999; 17\%).

\subsubsection{Advantages and limits}

These measurements seem to have some advantages. According to the protocol used, they highlighted the reliability of the measurements (low impact of the people making the measurements; $67 \%$ ) but so the high cost $(83 \%)$, the time-consuming aspect (33\%) and the significant technical difficulties $(33 \%)$. Furthermore, one laboratory notices that interference can occur between certain metals.

\subsubsection{Synthesis}

The contamination of $P$. oceanica by trace metals provides information about the level of pollutants accumulated by the plant, and thus, about the overall contamination of the environment.

\section{Discussion and conclusions}

The number of answers is sufficient to obtain representative results, according to the minimum number of informants needed by the domain of the questionnaire (Weller and Romney, 1988).

A recapitulative plan can be proposed (Fig. 5), which clarify the main descriptors of Posidonia oceanica, with, for each descriptor, the different parameters used and their methods.

Concerning the acquisition of data, an in situ approach of the meadow seems to be the strategy first and foremost developed by the people, because it allows direct and visual estimations of the status of the meadow. The descriptors most commonly used (density, upper and lower depth limits) give information at the population level (Table 4). Generally they are studied by satisfactory methods that can be applied directly on field. Even if they sometimes require diving techniques, one of their advantages is that they are not destructive. Furthermore these descriptors (density and bathymetric positions of the meadow) benefit from a protocol that is applied, quite homogeneously, by all the laboratories. However, with density, the type of quadrat and/or the number of replications vary from one laboratory to another. The reason of the choice (specific size) is not mentioned, but the time of investigations increases in relation with the surface to be studied (Panayotidis et al., 1981), and a smaller quadrat is easier to use (e.g bulk). Nevertheless, a minimal surface of $1600 \mathrm{~cm}^{2}$ is required to obtain a reduced size of the standard error (Panayotidis et al., 1981), which can be realized with a quadrat of at least 0.4 $\mathrm{m}$, and by only $42 \%$ of the laboratories (Table 2 ). The number of replicas must also be taken into account. An error of less than $20 \%$ (Boudouresque et al., 1990) is needed to the estimation of the mean density. Concerning the quadrat of $0.4 \mathrm{~m}$, a number of 10 replicas (i.e. a $16,000 \mathrm{~cm}$ surface area) fulfils this condition (Pergent et al., 1995), and allows to take into account the aggregative structure of the meadow (Panayotidis et al., 1981). The use of a circle ( $0.3 \mathrm{~m}$ diameter) seems to be sufficient, or even excessive, if at least 30-50 replicas are carried out (Table 2). Similar approach is carried out on herbaceous plants through the size and the shape of the quadrat as well as for the number of replicates (Elzinga et al., 2001). 
Fig. 5. Recapitulative plan of the main descriptors of Posidonia oceanica, with the measured parameters the methods of investigation: (1) Meinesz et al. (1988); (2) Lefevre et al. (1984); (3) Pasqualini et al. (1997); (4) Mc Kenzie et al. (2003); (5) Augier et al. (1984); (6) Boudouresque et al. (2000); (7) Balduzzi et al. (1981); (8) Dauby and Poulicek (1995); (9) Cinelli et al. (1984); (10) Morri (1991); (11) Buia et al. (2003); (12) Giraud (1977); (13) Giraud (1979); (14) Drew and Jupp (1976); (15) Blanc (1956); (16) Clairefond and Jeudy De Grissac (1979); (17) Willsie (1987); (18) Pergent et al. (1995); (19) Pergent (1990); (20) Duarte (1991b); (21) Cebrian et al. (1994); (22) Mateo et al. (1997); (23) Pergent et al. (1989); (24) Panayotidis et al. (1981); (25) Romero (1986); (26) Meinesz and Laurent (1978); (27) Duarte and Kirkman (2003); (28) Francour et al. (1999); (29) Ramos-Martos and Ramos-Espla (1989); (30) Pasqualini et al. (2000); (31) Blanc-Vernet (1984); (32) Russo and Vinci (1991); (33) Harmelin-Vivien and Francour (1992); (34) Hamoutene et al. (1995); (35) Ferrat et al. (2002); (36) Mateo and Sabate (1993); (37) Gobert et al. (1995) and (38) Romeo et al. (1995).

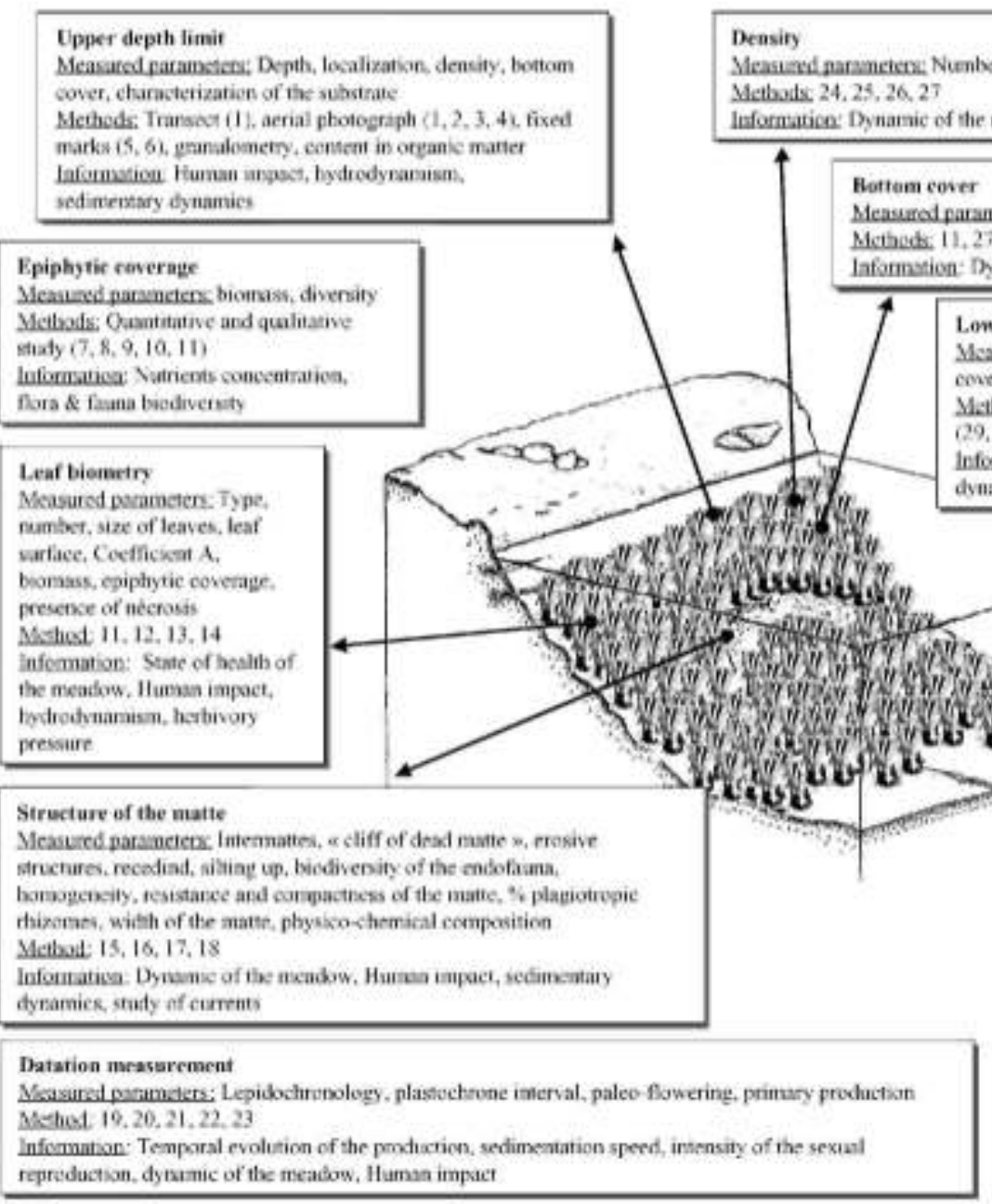

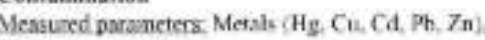
Radioelement $(\mathrm{Cs})$

Methods ICPS, Spectiopbotensetry (38)

Information: Thumas impact

The acquisition of a descriptor is only the first step in its use: an interpretation scale is required to make the descriptor effective. Three of the most commonly used descriptors (density, lower depth limit and epiphytic coverage) were investigated according to this aim. With respect to density, the scale of Giraud (1977) remains in common use because it is simple to implement (six classes with precisely defined markers). Nevertheless, it should be noticed that this scale does not take into consideration the normal decrease in meadow density in function of depth or the type of substrate. The attempt at classification proposed by Romero-Martinengo (1985), which introduced the effect of depth, was difficult to use because of the lack of some of the parameters needed to calculate it (e.g. coefficient of light attenuation). The scale proposed by Pergent et al. (1995) includes the depth parameter, by means of a logarithmic factor, on the basis of bibliographical data concerning stations submitted to varying degrees of human pressure. Its aim is both to compare stations situated at different depths (this cannot be done with the scale of Giraud, 1977) and to evaluate the "normal" level of density and the quality of the environment in general. However, it needs to be improved by incorporating a greater quantity of data and also by a more precise determination of the human characteristics of the site and the type of bottom (e.g. soft or hard). The limits of use of both scales must be taken into account when using them. Concerning the position of the 
lower depth limit, only the scale of Pergent et al. (1995) correlates the mean depth to the clarity of water. The other scales used concern the type of limits (Meinesz and Laurent, 1978; Boudouresque and Meinesz, 1982). These two types of scales should be used in tandem because they provide information about different environmental conditions.

Table 4 Directs and secondary impacts on Posidonia oceanica descriptors and their time of answers

\begin{tabular}{|c|c|c|c|c|c|}
\hline & \multirow{2}{*}{$\begin{array}{l}\text { Level of } \\
\text { information }\end{array}$} & \multirow[t]{2}{*}{ Direct impact } & \multirow[t]{2}{*}{ Secondary impact } & \multicolumn{2}{|c|}{ Time of answer } \\
\hline & & & & $\begin{array}{l}\text { In case of } \\
\text { improvement }\end{array}$ & $\begin{array}{l}\text { In case of } \\
\text { deterioration }\end{array}$ \\
\hline Density & Population & Water transparency & $\begin{array}{l}\text { Anchoring } \\
\text { Nutrients concentration }\end{array}$ & Annual & Annual \\
\hline Lower depth limit & Population & Water transparency & $\begin{array}{l}\text { Trawling } \\
\text { Water movement } \\
\text { Sedimentary dynamics } \\
\text { Nutrients concentration }\end{array}$ & Decades & Annual \\
\hline Upper depth limit & Population & $\begin{array}{l}\text { Coastal } \\
\text { development } \\
\text { Sedimentary } \\
\text { dynamics }\end{array}$ & Water movement & Decades & $\begin{array}{l}\text { Monthly to } \\
\text { annual }\end{array}$ \\
\hline Epiphytic coverage & Individual & $\begin{array}{l}\text { Nutrients } \\
\text { concentration }\end{array}$ & $\begin{array}{l}\text { Herbivory pressure } \\
\text { Water transparency } \\
\text { Water movement }\end{array}$ & Monthly & Monthly \\
\hline Matte structure & Population & $\begin{array}{l}\text { Sedimentary } \\
\text { dynamics } \\
\text { Water movement }\end{array}$ & $\begin{array}{l}\text { Anchoring } \\
\text { Trawling }\end{array}$ & Decades & $\begin{array}{l}\text { Monthly to } \\
\text { annual }\end{array}$ \\
\hline Leaf biometry & Individual & $\begin{array}{l}\text { Nutrients } \\
\text { concentration } \\
\text { Water transparency }\end{array}$ & $\begin{array}{l}\text { Water movement } \\
\text { Herbivory pressure }\end{array}$ & $\begin{array}{l}\text { Monthly to } \\
\text { annual }\end{array}$ & $\begin{array}{l}\text { Monthly to } \\
\text { annual }\end{array}$ \\
\hline Bottom cover & Population & $\begin{array}{l}\text { Sedimentary } \\
\text { dynamics } \\
\text { Water transparency } \\
\text { Trawling }\end{array}$ & $\begin{array}{l}\text { Water movement } \\
\text { Anchoring }\end{array}$ & $\begin{array}{l}\text { Annual to } \\
\text { decades }\end{array}$ & $\begin{array}{l}\text { Monthly to } \\
\text { annual }\end{array}$ \\
\hline $\begin{array}{l}\text { Species associated to } \\
\text { the meadow }\end{array}$ & Population & $\begin{array}{l}\text { Herbivory pressure } \\
\text { Competition } \\
\text { Invasive species }\end{array}$ & $\begin{array}{l}\text { Water movement } \\
\text { Chemical inputs } \\
\text { Organic matter } \\
\text { concentration } \\
\text { Nutrients concentration }\end{array}$ & Annual & $\begin{array}{l}\text { Monthly to } \\
\text { annual }\end{array}$ \\
\hline $\begin{array}{l}\text { Datation } \\
\text { measurement }\end{array}$ & Individual & $\begin{array}{l}\text { Sedimentary } \\
\text { dynamics } \\
\text { Water transparency }\end{array}$ & Herbivory pressure & Annual & Annual \\
\hline $\begin{array}{l}\text { Biochemical and } \\
\text { chemical }\end{array}$ & Tissue & $\begin{array}{l}\text { Nutrients } \\
\text { concentration }\end{array}$ & Sedimentary dynamics & $\begin{array}{l}\text { Weekly to } \\
\text { monthly }\end{array}$ & Daily to weekly \\
\hline & & $\begin{array}{l}\text { Water transparency } \\
\text { Chemical inputs }\end{array}$ & $\begin{array}{l}\text { Organic matter } \\
\text { concentration } \\
\text { Invasive species } \\
\text { Competition }\end{array}$ & & \\
\hline Contamination & Tissue & Chemical inputs & & Monthly & $\begin{array}{l}\text { Weekly to } \\
\text { monthly }\end{array}$ \\
\hline
\end{tabular}

Most of the descriptors appear to provide pertinent information about the vitality of the meadow and more generally about the quality of the environment. Some of them provide data about the disturbances in a more specific way, and it is even possible to identify direct and indirect causes of temporal and spatial changes (Table 4). For instance, that is the case of the bathymetric position of the lower depth limit, which is directly linked to changes in water transparency (Duarte, 1991a; Dennison et al., 1993). Also, several authors make a direct connection between the epithytic coverage (at quantitative and/or qualitative level) and the rate of nutrient enrichment of the environment (Coleman and Burkholder, 1994; Harlin, 1993; Lin et al., 1996; Pergent-Martini 
et al., 1996). Similarly contamination can be studied specifically through the plant's high ability to concentrate trace metals (see synthesis in Pergent-Martini and Pergent, 2000). On the other hand descriptors, such as the leaf biometry or the species associated to the meadow, seem to supply information less specific and globally express the vitality of the meadow and its high sensitivity to environmental change (Table 4). According to the great variability of the disturbances (e.g. nutrient inputs, decrease of water transparency, water movements) and the time of answer of the various descriptors of the meadow (weekly to decades), a combination of different descriptors is therefore often used (Table 4). This global approach, which allows a better understanding of the interactions and complexity of the disturbances, must be recommended.

Beyond the explanatory aspect, it must bear in mind that a "good descriptor" on the Mediterranean scale must: (i) provide reliable information about the quality of the environment; (ii) be used by most people and (iii) allowed to answer to the actual preoccupations of the stakeholders and the managers. The objectives of this paper is not to provide a "Posidonia method book", that all Mediterranean scientist must applied, but to present the state of the art of descriptors, mainly used to evaluate environmental quality through $P$. oceanica characterization, and to offer the opportunity to choice between different descriptors able to facilitate the monitoring of this species. This need of monitoring is linked to the actual status of $P$. oceanica, as a protective species that must be conserved (Mediterranean Action Plan of Marine Vegetation; UNEP) but so the need of adequate tools for European countries to classify the status of coastal water, as required by the Water Framework Directive, in which Posidonia meadows are considered as biological quality elements. This preoccupation exceed the only Posidonia meadows or/and the Mediterranean sea: similar approaches are in process, threw the world, with experiences, like the Seagrass Monitoring Network, initiated since 2000 (see http:// www.worldseagrass.org; Short and Coles, 2001).

\section{Acknowledgements}

This work benefited partly from the financial support of the European program ГNTERREG IIIA Corsica, Sardinia. Tuscany. Authors thank the reviewers for their suggestions, which allowed improving this document.

\section{References}

Adami, G., Barbieri, P., Fabiani, M., Piselli, S., Predonzani, S., Reisenhofer, E., 2002. Levels of cadmium and zinc in hepato-pancreas of reared Mytilus galloprovincialis from the Gulf of Trieste (Italy). Chemosphere 48 (7), 671-677.

Ardizzone, G.D., Belluscio, A., 1992. Cartografia delle praterie di Posidonia oceanica lungo le coste laziali. Oebalia XVII (Suppl.), 539-541.

Augier, H., 1985. L'herbier à Posidonia oceanica, son importance pour le littoral méditerranéen, sa valeur comme indicateur biologique de l'état de santé de la mer, son utilisation dans la surveillance du milieu, les bilans écologiques et les études d'impact. Vie marine 7, 85-113.

Augier, H., Nieri, M., Gilli, A., Martinet, P., Stephan, G, Ventron, G, 1984. Balisage et cartographie de l'herbier de Posidonies au droit des plages artificielles de la baie de la Ciotat (B.D.R., France). In: Boudouresque, C.F., Jeudy de Grissac, A., Olivier, J. (Eds.), International Workshop Posidonia oceanica Beds. GIS Posidonie, Marseille, pp. 79-85.

Balduzzi, A., Boero, F, Pansini, M., Pronzato, R., 1981. A method for semiquantitative samplings of the sessile epifauna of the Posidonia oceanica beds. CIESM 27 (9), 247-248.

Bhattacharya, B., Sarkar, S.K., Das, R., 2003. Seasonal variations and inherent variability of selenium in marine biota of a tropical wetland ecosystem: implications for bioindicator species. Ecol. Indicat. 2 (4), 367-375.

Bell, J.D., Harmelin-Vivien, M.L., 1983. Fish fauna of french mediterranean Posidonia oceanica seagrass meadows feeding habits. Téthys 11 (1), 1-14.

Bianchi, C.N., Bedulli, D., Morri, C, Occhipinti Ambrogi, A., 1989. L'herbier de Posidonies: ecosystème ou carrefour écoéthologique? In: Boudouresque, C.F, Meinesz, A., Fresi, E., Gravez, V. (Eds.), International Workshop Posidonia oceanica Beds. GIS Posidonie, Marseille, pp. 257-272.

Blanc, J.J., 1956. Etudes géologiques et sédimentologiques. Ann. Inst. Oceano. 32, 123-153.

Blanc-Vernet, L., 1984. Les Foraminifères de l'herbier à Posidonia oceanica en Méditerranée: analyse des assemblages, aspects régionaux, application aux microfaunes fossiles. In: Boudouresque, C.F., Jeudy de Grissac, A., Olivier, J. (Eds.), International Workshop Posidonia oceanica Beds. GIS Posidonie, Marseille, pp. 3-14.

Blandin, P., 1986. Bioindicateurs et diagnostic des systèmes écologiques. Bull. Ecol. 17 (4), 211-307.

Boudouresque, C.F, Bertrandy, M.C., Bouladier, E., Foret, P., Meinesz, A., Pergent, G., Vitiello, P., 1990. Le réseau de surveillance des herbiers de Posidonies mis en place en région Provence-Alpes-Côte d'Azur (France). CIESM 32 (1), 1-11.

Boudouresque, C.F., Charbonnel, E., Meinesz, A., Pergent, G., Pergent-Martini, C., Cadiou, G., Bertrandy, M.C., Foret, P., Ragazzi, M., Rico-Raimondino, V., 2000. A monitoring network based on the seagrass Posidonia oceanica in the Northwestern Mediterranean sea. Biol. Mar. Medit. 7 (2), 328-331.

Boudouresque, C.F., Giraud, G., Panayotidis, P., 1980. Végétation marine de l'île de Port-Cros (Pare National). XIX Mise en place d'un transect permanent. Trav. Sci. Parc Nat. Port-Cros 6, 207-221. 
Boudouresque, C.F., Meinesz, A., 1982. Découverte de l'herbier de Posidonies. Cah. Parc Nat. Port-Cros 4, 1-79.

Braun-Blanquet, J., 1964. Pflanzensoziologie. Springer, Wien.

Buia, M.C., Gambi, M.C., Dappiano, M., 2003. I sistemi a faner-ogame marine. Biol. Mar. Medit. 10, 145-198.

Castilla, J.C., 1996. Copper mine tailing disposal in northern Chile rocky shores: Enteromorpha compressa (Chlorophyta) as a sentinel species.. Environ. Monit. Assess. 40 (2), 171-184.

Cebrian, J., Marbà, N., Duarte, C.M., 1994. Estimating leaf age of the seagrass Posidonia oceanica (L.) Delile using the plasto-chrone interval index. Aquat. Bot. 49 (1), 59-65.

CIESM, 2002. Mediterranean Mussel-Watch - Designing a regional programm for detecting radionuclides and trace contaminants. CIESM Workshop Series, Monaco, vol. 15, 136 pp.

Cinelli, F., Cormaci, M., Furnari, G., Mazzella, L., 1984. Epiphytic macroflora of Posidonia oceanica (L.) Delile leaves around the island of Ischia (Gulf of Naples). In: Boudouresque, C.F., Jeudy de Grissac, A., Olivier, J. (Eds.), International Workshop Posidonia oceanica Beds. GIS Posidonie, Marseille, pp. 91- 99.

Clairefond, P., Jeudy De Grissac, A., 1979. Description et analyse de structures sédimentaires en milieu marin: recensement de quel-ques exemples dans l'herbier de Posidonies autour de l'île de Port-Cros (Parc National). Trav. Sci. Parc. Nat. Port-Cros 5, 79-104.

Coleman, V.L., Burkholder, J.M., 1994. Community structure and productivity of epiphytic microalgae on eelgrass (Zostera marina L.) under water-column nitrate enrichment. J. Exp. Mar. Biol. Ecol. 179, 29-48.

Costanza, R., Arge, R., de Groot, R., Farber, S., Grasso, M., Hannon, B., Limburg, K., Naeem, S., O'Neill, R.V., Paruelo, J., Raskin, R.G., Sutton, P., Van den Belt, M., 1997. The value of the world's ecosystem services and natural capital. Nature 387, 253-260.

Dauby, P., Poulicek, M., 1995. Methods for removing epiphytes from seagrasses: SEM observations on treated leaves. Aquat. Bot. 52 (3), 217-228.

Delgado, O., Ruiz, J., Perez, M., Romero, J., Ballesteros, E., 1999. Effects of fish farming on seagrass (Posidonia oceanica) in a Mediterranean bay: seagrass decline after organic loading cessation. Oceanol. Acta 22 (1), 109-117.

Dennison, W.C., Orth, R.J., Moore, K.A., Stevenson, J.C., Carter, V., Kollar, S., Bergstrom, P.W., Batiuk, R.A., 1993. Assessing water quality with submersed aquatic vegetation - habitat requirements as barometer of Chesapeake bay health. Bioscience 43 (2), 86-94.

Drew, E.A., Jupp, B.P., 1976. Some Aspects of the Growth of Posidonia oceanica in Malta Underwater research. Academic Press, London. Duarte, C.M., 1991a. Seagrass depth limits. Aquat. Bot. 40, 363-377.

Duarte, C.M., 1991b. Allometric scaling of seagrass form and productivity. Mar. Ecol. Progr. Ser. 77, 289-300.

Duarte, C.M., 1999. Seagrass ecology at the turn of millenium: challenges for the new century. Aquat. Bot. 65, 7-20.

Duarte, C.M., 2002. The future of seagrass meadows. Environ. Conserv. 29 (2), 192-206

Duarte, C.M., Kirkman, H., 2003. Methods for the measurement of seagrass abundance and depth distribution. In: Short, FT, Coles, G.R. (Eds.), Global Seagrass Research Methods. Elsevier Scientific Publishers B.V., Amsterdam, pp. 141-154.

Elzinga, C.L., Salzer, D.W., Willoughby, J.W., Gibbs, J.P., 2001. Monitoring Plant and Animal Populations. Maiden. Blackwell Science, Massachusetts, $360 \mathrm{pp}$.

Ferrat, L., Pergent-Martini, C., Fernandez, C., Roméo, M., 2002. Is glutathione transferase (GST) activity in Posidonia oceanica a stress response to mercury exposure? Bull. Mar. Sci. 71 (3), 1183-1190.

Fourqurean, J.W., Cai, Y., 2001. Arsenic and phosphorus in seagrass leaves from the Gulf of Mexico. Aquat. Bot. 71 (4), $247-258$.

Francour, P., Ganteaume, A., Poulain, M., 1999. Effects of boat anchoring in Posidonia oceanica seagrass beds in the Port-Cros national park (north-western Mediterranean sea). Aquat. Conserv. 9, 391-400.

Gambi, M.C., Buia, M.C., Casola, E., Scardi, M., 1989. Estimates of water movement in Posidonia oceanica beds: a first approach. In: Boudouresque, C.F., Meinesz, A., Fresi, E., Gravez, V. (Eds.), International Workshop Posidonia oceanica Beds. GIS Posidonie, Marseille, pp. 101-112.

Giraud, G., 1977. Essai de classement des herbiers de Posidonia oceanica (Linné) Delile. Bot. Mar. 20 (8), $487-491$.

Giraud, G., 1979. Sur une méthode de mesure et de comptage des structures foliaires de Posidonia oceanica (Linnaeus) Delile. Bull. Muséum Hist. Nat. Marseille 39, 33-39.

Gobert, S., Belkhiria, S., Dauby, P., Havelange, S., Soullard, M., Bouquegneau, J.M., 1995. Variations temporelles de la phéno-logie et de la composition biochimique de la phanérogame marine Posidonia oceanica en baie de Calvi. Bull. Socié. R. Sci. Liège 64 (4-5), $263-284$.

Guilizzoni, P., 1991. The role of heavy metals and toxic materials in the physiological ecology of submersed macrophytes. Aquat. Bot. 41, 87-109.

Hamoutene, D., Mathieu, A., Hofmann, P., Salaun, J.P., Lafaurie, M., 1995. Preparation and characterization of subcellular fractions suitable for studies of xenobiotic metabolism from leaf sheaths of a marine seagrass: Posidonia oceanica (Linnaeus) Delile. Mar. Environ. Res. 39 (14), 249-253.

Harlin, M.M., 1993. Changes in major plant groups following nutrient enrichment. In: McComb, A.J. (Ed.), Eutrophic Shallow Estuaries and Lagoons. CRC Press Inc., Boca Raton, FL, pp. 173-187.

Harmelin-Vivien, M.L., Francour, P., 1992. Trawling or visual censuses? Methodological bias in the assessment of fish populations in seagrass beds. Mar. Ecol. 13 (1), 41-51. 
Jeudy de Grissac, A., Boudouresque, C.F., 1985. Rôles des herbiers de phanérogames marines dans les mouvements des sédiments côtiers: les herbiers à Posidonia oceanica. In: Ceccaldi, H.J., Champalbert, G. (Eds.), Les aménagements côtiers et la gestion du littoral, Coll. pluridisciplinaire franco-japonais océanographie. 143-151.

Lefevre, J.R., Valerio, C., Meinesz, A., 1984. Optimisation de la technique de la photographie aérienne pour la cartographie des herbiers de Posidonies. In: Boudouresque, C.F., Jeudy de Grissac, A.,Olivier, J. (Eds.), International Workshop Posidonia oceanica Beds. GIS Posidonie, Marseille, pp. 49-55.

Lin, H.J., Nixon, S.W., Taylor, D.I., Granger, S.L., Buckley, B.A., 1996. Responses of epiphytes on eelgrass, Zostera marina L., to separate and combined nitrogen and phosphorus enrichment. Aquat. Bot. 52, 243-258.

Linton, D.M., Warner, G.F., 2003. Biological indicators in the Caribbean coastal zone and their role in integrated coastal management. Ocean Coast. Manag. 46 (3-4), 261-276.

Lionetto, M.G., Caricato, R., Giordano, M.E., Pascariello, M.F., Marinosci, L., Schettino, T., 2003. Integrated use of biomarkers (acetylcholinesterase and antioxidant enzymes activities) in Mytilus galloprovincialis and Mullus barbatus in an Italian coastal marine area. Mar. Pollut. Bull. 46 (3), 324-333.

Mateo, M.A., Romero, J., Perez, M., Littler, M.M., Littler, D.S., 1997. Dynamics of millenary organic deposits resulting from the growth of the Mediterranean seagrass Posidonia oceanica.. Estuar, Coast. Shelf Sci. 44 (1), 103-110.

Mateo, M.A., Sabate, S., 1993. Wet digestion of vegetable tissue using a domestic microwave oven. Anal. Chim. Acta 279, 273-279.

Mc Kenzie, L.J., Finkbeiner, M.A., Kirkman, H., 2003. Methods for mapping seagrass distribution. In: Short, F.T., Coles, R.G. (Eds.), Global Seagrass Research Methods. Elsevier Scientific Publishers B.V., Amsterdam, pp. 101-122.

Meinesz, A., Boudouresque, C.F., Lefevre, J.R., 1988. A map of the Posidonia oceanica beds of Marina d'Elbu (Corsica, Mediterranean). Mar. Ecol. 9 (3), 243-252.

Meinesz, A., Laurent, R., 1978. Cartographie et état de la limite inférieure de l'herbier de Posidonia oceanica dans les Alpes-maritimes (France), Campagne Poseidon 1976. Bot. Mar. 21 (8), 513-526.

Morri, C, 1991. Présentation d'un indice synthétique pour l'évaluation de l'épiphytisme foliaire chez Posidonia oceanica (L.) Delile. Posidonia Newslett. 4 (1), 33-37.

Nienhuis, P.H., 1986. Background levels of heavy metals in nine tropical seagrass species in Indonesia. Mar. Pollut. Bull. 17 (11), $508-511$.

Panayotidis, P., Boudouresque, C.E, Marcot-Coqueugniot, J., 1981. Microstructure de l'herbier de Posidonia oceanica (Linnaeus) Delile. Bot. Mar. 24 (3), 115-124.

Pasqualini, V., Clabaut, P., Pergent, G., Benyoussef, L., Pergent-Martini, C., 2000. Contribution of side scan sonar to the management of Mediterranean littoral ecosystems. Int. J. Remote Sensing 21 (2), 367-378.

Pasqualini, V., Pergent-Martini, C., Clabaut, P., Pergent, G., 1998. Mapping of Posidonia oceanica using aerial photographs and side-scan sonar: application of the island of Corsica (France). Estuar. Coast. Shelf Sci. 47 (3), 359-367.

Pasqualini, V., Pergent-Martini, C., Fernandez, C., Pergent, G., 1997. The use of airborne remote sensing for benthic cartography: advantages and reliability. Int. J. Remote Sensing 18 (5), 1167-1177.

Pergent, G., 1990. Lepidochronological analysis in the seagrass Posidonia oceanica: a standardized approach. Aquat. Bot. $37,39-54$.

Pergent, G., 1991. Les indicateurs écologiques de la qualité du milieu marin en Méditerranée. Oceanis 17 (4), $341-350$.

Pergent, G., Ben Maiz, N., Boudouresque, C.F., Meinesz, A., 1989. The flowering of Posidonia oceanica over the past fifty years: a lepidochronological study. In: Boudouresque, C.E, Meinesz, A., Fresi, E., Gravez, V. (Eds.), International Workshop Posidonia oceanica Beds. GIS Posidonie, Marseille, pp. 69-76.

Pergent, G., Pergent-Martini, C., Boudouresque, C.F., 1995. Utilisation de l'herbier à Posidonia oceanica comme indicateur bio-logique de la qualité du milieu littoral en Méditerranée: Etat des connaissances. Mésogée 54, 3-29.

Pergent-Martini, C, 1998. Posidonia oceanica: a biological indicator of past and present mercury contamination. Mar. Environ. Res. 45 (2), 101-111.

Pergent-Martini, C, Pergent, G., Fernandez, C, Ferrat, L., 1999. Value and use of Posidonia oceanica as a biological indicator. In: Ozhan, E., (Ed.), Land-ocean interactions: managing coastal ecosystems. Proceeding MEDCOAST 99-EMECS 99 Joint Conference MEDCOAST, Middle East Technical Univ. Publ, Ankara. 73-90.

Pergent-Martini, C, Pergent, G., 2000. Are marine phanerogams a valuable tool in the evaluation of marine trace-metal contamination: example of the Mediterranean sea? Int. J. Environ. Pollut. 13 (1-6), 126-147.

Pergent-Martini, C, Rico-Raimondino, V., Pergent, G., 1996. Impacts des nutriments sur les herbiers à Posidonia oceanica-Données préliminaries. J. de Recherche Océanographi-que 21 (1-2), 35-39.

Procaccini, G., Buia, M.C., Gambi, M.C., Perez, M., Pergent, G., Pergent-Martini, C., Romero, J., 2003. The seagrasses of the Western Mediterranean. In: Green, E.P., Short, F.T. (Eds.), World Atlas of Seagrasses. University of California Press, pp. 48-58.

Ramos-Martos, A., Ramos-Espla, A.A., 1989. Utilization of acoustic methodes in the cartography of the Posidonia oceanica bed in the bay of Alicante (SESpain). Posidonia Newslett. 2 (1), 17-19.

Romeo, M., Gnassia-Barelli, M., Juhel, T., Meinesz, A., 1995. Memorization of heavy metals by scales of the seagrass Posidonia oceanica, collected in the NW Mediterranean. Mar. Ecol. Prog. Ser 120 (1-3), 211-218.

Romero, J., 1986. Note sur une méthode d'évaluation de la densité des faisceaux dans les herbiers de Posidonies. CIESM 30 (2), 266. 
Romero, J., Alcoverro, T., Martinez-Crego, B., Pérez, M., 2005. The seagrass Posidonia oceanica as a quality element under the Water framework Directive: POMI, a multivariate method to assess ecological status of Catalan coastal waters. Working document of the POMI group, University of Barcelona and Centre d'estudis Avançats de Blanes, $15 \mathrm{p}$.

Romero, J., Pergent, G., Pergent-Martini, C., Mateo, M.A., Regnier, C., 1992. The detritic compartment in a Posidonia oceanica meadow: litter features, decomposition rates and mineral stocks. Mar. Ecol. 13 (1), 73-83.

Romero-Martinengo, J., 1985. Estudio ecologico de las Faneroga-mas marinas de la costa Catalana: Produccion primaria de Posidonia oceanica (L.) Delile en las islas Medes, Tesis Doct. Facultad Biol. Univ. Barcelon, Spain.

Ruiz, J.M., Pérez, M., Romero, J., 2001. Effects of fish farm loadings on seagrass (Posidonia oceanica) distribution, growth and photosynthesis. Mar. Pollut. Bull. 42 (9), 749-760.

Ruiz, J.M., Romero, J., 2003. Effects of disturbances caused by coastal constructions on spatial structure, growth dynamics and photosynthesis of the seagrass Posidonia oceanica. Mar. Pollut. Bull. 46, 1523-1533.

Russo, G.F., Vinci, D., 1991. The hand towed net method in Posidonia oceanica beds. 1. A preliminary study on the sample size for gatsropod taxocene in a shallow stand. Posidonia News-lett. 4 (1), 27-31.

Short, F.T., Coles, R.G., 2001. In: Short, Coles, (Eds.), Global seagrass research methods. Elsevier Science B.V., p. 473.

Short, F.T., Wyllie-Echeverria, S., 1996. Natural and human-induced disturbance of seagrasses. Environ. Conserv. 23 (1), 17-27.

Storelli, M.M., Storelli, A., Marcotrigiano, G.O., 2001. Heavy metals in the aquatic environment of the Southern Adriatic Sea, Italy: Macroalgae, sediments and benthic species. Environ. Int. 26 (7-8), 505-509.

Strauss, A., Corbin, J., 1998. Basics of qualitative research: Grounded theory procedures and techniques, second ed. SAGE Publications, Newbury Park, p. 312.

Thomann, R.V., Mahony, J.D., Mueller, R., 1995. Steady-state model of biota sediment accumulation factor for metals in two marine bivalves. Environ. Toxicol. Chem. 14 (11), 1989-1998.

Weller, S.C., Romney, A.K., 1988. Systematic Data Collection. SAGE Publications, Newbury Park, p. 96.

Willsie, A., 1987. Structure et fonctionnement de la macrofaune associée à la matte morte et d'herbier vivant de Posidonia oceanica (L.) Delile: influence des facteurs abiotiques et bio-tiques. Thesis Oceanology, Aix-Marseille II University.

Yamamuro, M., Kayanne, H., Yamano, H., 2003. $\delta^{15} \mathrm{~N}$ of seagrass leaves for monitoring anthropogenic nutrient increases in coral reef ecosystems. Mar. Pollut. Bull. 46 (4), 452-458. 